\title{
PENGARUH PENDAPATAN SUAMI, TINGKAT PENDIDIKAN, UMUR DAN KESEMPATAN KERJA TERHADAP JUMLAH JAM KERJA BURUH WANITA PADA GUDANG TEMBAKAU "GMIT" JEMBER
}

\author{
SOVIA ANGGRAINI SETIONO* \\ ACHADYAH PRABAWATI \\ Program Studi Administrasi Bisnis \\ Sekolah Tinggi Ilmu Administrasi Pembangunan Jember \\ *Email: cophiaayu@gmail.com
}

\begin{abstract}
ABSTRAK
Penelitian ini bertujuan untuk mengetahui dan mennguji pengaruh yang signifikan variabel pendapatan keluarga, tingkat pendidikan, umur dan

kesempatan kerja terhadap jumlah jam kerja buruh wanita pada Gudang

Tembakau "GMIT" Jember. Metode penelitian yang dilakukan adalah deskriptif kuantitatif dengan penentuan responden secara purposive sampling yang berjumlah 58 orang.

Hasil penelitian menunjukkan bahwa berdasarkan perhitungan uji regresi diperoleh bahwa variabel pendapatan suami berpengaruh signifikan terhadap jumlah jam kerja sebesar 0,837 . Tingkat pendidikan berpengaruh signifikan terhadap jumlah jam kerja sebesar 0,016. Umur berpengaruh signifikan terhadap jumlah jam kerja sebesar 0.017. Kesempatan kerja berpengaruh signifikan terhadap jumlah jam kerja sebesar 0,024 .

Berdasarkan perhitungan tersebut diketahui bahwa variabel pendapatan suami memiliki pengaruh yang lebih dominan terhadap jumlah jam kerja buruh wanita pada Gudang Tembakau "GMIT" Jember. Pengujian variabel independen yaitu pendapatan suami, tingkat pendidikan, umur dan kesempatan kerja secara bersama dapat menjelaskan jumlah jam kerja sebesar 0,802 atau $80,2 \%$. Hal ini diperkuat dengan diperolehnya nilai $\mathbf{F}$ hitung yang signifikan yaitu sebesar 31,029.
\end{abstract}

Kata Kunci: Pendapatan Suami, Tingkat Pendidikan, Umur, Kesempatan Kerja 


\section{PENDAHULUAN}

Peningkatan jumlah penduduk Kabupaten Jember dari tahun ke tahun menyebabkan jumlah tenaga kerja mengalami perubahan yang cepat, khususnya tenaga kerja perempuan. Kesempatan kerja bagi perempuan makin lama makin terbuka lebar serta semakin bertambah banyak secara kuantitatif, sehingga menyebabkan semakin banyaknya wanita yang masuk ke pasar kerja. Perempuan memberikan sumbangan yang besar bagi kelangsungan perekonomian dan kesejahteraan rumah tangga serta masyarakat. Dengan adanya perempuan bekerja akan dapat mengangkat kesejahteraan keluarga pekerja karena mendapat tambahan penghasilan dari hasil kerja mereka. Fenomena tersebut menunjukkan peran perempuan sebagai ibu rumah tangga dan sebagai pencari nafkah di dalam usaha meningkatkan taraf hidup keluarga.

Menurut Payaman (2001:39) terdapat beberapa faktor yang mempengaruhi jam kerja seseorang selain upah yaitu variabel kependudukan meliputi jenis kelamin, umur dan tanggungan keluarga. Masing-masing kelompok umur wanita mempunyai tingkat partisipasi yang berbeda-beda tergantung status perkawinan dan tingkat pendidikan. Wanita dalam mencurahkan jam kerja untuk mencari pendapatan tambahan bertujuan untuk memperbaiki perekonomian keluarganya agar memdapatkan kehidupan yang layak, dan juga dapat membiayai kebutuhan anak-anak mereka, sehingga mereka dapat meringankan suami mereka yang berpendapatan sangat sedikit, tetapi tidak melupakan kodrat mereka sebagai seorang wanita yang harus mengurus rumah tangga, seperti mencuci, memasak, mengasuh anak dan lain-lain. Jumlah jam kerja buruh wanita pada gudang tembakau "GMIT" Jember tentunya tergantung pada jam kerja masingmasing dan seberapa besar usaha yang dijalankan. Variabel yang dapat mempengaruhi jumlah jam kerja buruh wanita adalah pendapatan suami, tingkat pendidikan, umur dan kesempatan kerja. 
Pendapatan suami merupakan salah satu alasan terpenting, kenapa seorang wanita mencurahkan jamnya untuk mencari nafkah bagi keluarga, dengan mencari tambahan pendapatan selain dari pendapatan suami sehingga dapat membantu perekonomian keluarga. terpenuhi. Sedangkan umur adalah faktor yang mempengaruhi wanita dalam mencurahkan jam kerjanya, jika seorang wanita sudah berumur 18 tahun $\mathrm{k}$ eatas, maka akan bertambah juga tanggung jawab yang harus diterima sehingga harus mencari pekerjaan agar bisa memenuhi kebutuhan baik secara pribadi maupun keluarganya. Tingkat pendidikan merupakan faktor vital bagi kehidupan seseorang, khususnya bagi wanita. Semakin

\section{TINJAUAN PUSTAKA}

\subsection{Pengertian Pendapatan}

Pendapatan adalah penerimaan dana selama satu bulan karena hasil jerih payah seseorang dalam melakukan pekerjaan. Pendapatan adalah jumlah uang yang diterima oleh perusahaan dari aktivitasnya, kebanyakan dari penjualan produk tinggi tingkat pendidikan yang diraih oleh seseorang, semakin tinggi pula jabatan dan pekerjaan didapatkan sehingga dapat meningkatkan pendapatan wanita tersebut. Selanjutnya kesempatan kerja adalah banyaknya orang yang dapat tertampung untuk bekerja pada suatu perusahaan atau suatu instansi.

Berdasarkan latar belakang tersebut maka peneliti tertarik untuk melakukan penelitian guna memperoleh hasil yang relevan dengan kondisi di lapangan, sehingga dapat diketahui "Bagaimanakah Pengaruh Pendapatan Suami, Tingkat Pendidikan, Umur dan Kesempatan Kerja Terhadap Jumlah Jam Kerja Buruh Wanita Pada Gudang Tembakau GMIT Jember?"

dan/atau jasa kepada pelanggan. Bagi investor, pendapatan kurang penting dibanding keuntungan, yang merupakan jumlah uang yang diterima setelah dikurangi pengeluaran (Wikipedia).

$$
\text { Pendapatan suami adalah }
$$

penerimaan dana selama satu bulan 
untuk memenuhi kebutuhan hidup keluarganya dengan hasil jerih payah suami dalam melakukan pekerjaan. Penerimaan yang diperoleh dari pendapatan suami digunakan oleh istri dalam menentukan penawaran tenaga kerjanya. Pengaruh pendapatan terhadap kehidupan seseorang sangat penting sekali, karena pendapatan digunakan untuk memenuhi kebutuhan ekonomi. Apabila tingkat pendapatan lebih rendah dari tingkat kebutuhan akan mengakibatkan terjadinya ketidakseimbangan. Banyak sekali upaya yang dapat dilakukan seseorang untuk meningkatkan pendapatannya, selain memiliki pendapatan tetap biasanya banyak orang memilih untuk melakukan pekerjaan tambahan lainnya.

\subsection{Pengertian}

Tingkat

\section{Pendidikan}

Pendidikan sering diartikan sebagai usaha manusia untuk membina kepribadiannya sesuai dengan nilai-nilai di dalam masyarakat dan kebudayaan. Selanjutnya, pendidikan diartikan sebagai usaha yang dijalankan oleh seseorang atau kelompok orang lain agar menjadi dewasa atau mencapai tingkat hidup atau penghidupan yang lebih tinggi dalam arti mental (Hasbullah, 2009:1).

Selanjutnya dijelakan bahwa tingkat pendidikan dapat dibedakan berdasarkan tingkatan-tingkatan tertentu seperti:

1. Pendidikan dasar awal selama 9 tahun meliputi SD/sederajat, SLTP/sederajat.

2. Pendidikan lanjut

a. Pendidikan menengah minimal 3 tahun meliputi SMA atau sederajat

b. Pendidikan tinggi meliputi diploma, sarjana, magister, doktor dan spesialis yang diselenggarakan oleh perguruan tinggi.

\subsection{Pengertian Umur}

Menurut Hurlock (2007:20) umur adalah waktu seseorang sejak dilahirkansampai saat hidupnya yang dinyatakan dengan tahun. Usia > 18 tahun dinamakanremaja, dimana menurut piaget secara psikologi, masa remaja adalah usia 
dimanainduvidu berinteraksi dengan masyarakat dewasa dan termasuk juga perubahanintekektual yang mencolok. Pada masa remaja terjadi perubahan sikap dan prilaku, sebagian besar remaja bersikap ambivalen tehadap setiap perubahan. Usia18-40 tahun dinamakan dewasa dini dimana kemampuan mental mencapaipuncaknya dalam usia 20 tahun untuk mempelajari dan menyesuaikan diri padasituasi-situasi baru seperti pada misalnya mengingat hal-hal yang pernahdipelajari, penalaran analogis dan berfikir kreatif. Pada masa dewasa ini sering mencapai puncak prestasi. Umur > 40 tahun dinamakan usia madya dini dimanapada masa tersebut pada akhirnya ditandai perubahanperubahan jasmani danmental pada masa ini seseorang tinggal mempertahankan prestasi yang telah dicapainya pada usia dewasa.

\subsection{Pengertian Kesempatan Kerja}

Menurut Sukirno (2000:68) memberikan pengertian kesempatan kerja sebagai suatu keadaan dimana semua pekerja yang ingin bekerja pada suatu tingkat upah tertentu akan dengan mudah mendapat pekerjaan.

Jumlah penduduk sangat berpengaruh terhadap perkembangan kesempatan kerja, semakin tinggi jumlah penduduk yang termasuk dalam angkatan kerja maka kesempatan kerja yang tersedia harus semakin banyak. Luasnya kesempatan kerja ditandai dengan semakin banyaknya jumlah lapangan pekerjaan yang ditawarkan dari berbagai sektor ekonomi yang ada. Selain jumlah penduduk tingkat konsumsi juga berpengaruh terhadap penciptaan kesempatan kerja. Semakin tinggi tingkat konsumsi penduduk maka tingkat kesempatan kerja akan semakin meningkat karena peningkatan konsumsi akan diikuti oleh peningkatan permintaan tenaga kerja sehingga akan menyebabkan semakin tinggi pula kesempatan kerja.

\subsection{Pengertian Jam Kerja}

Jumlah jam kerja seluruh pekerjaan adalah lamanya waktu dalam jam yang digunakan untuk bekerja dari seluruh pekerjaan, tidak termasuk jam kerja istirahat resmi 
dan jam kerja yang digunakan untuk hal-hal di luar pekerjaan selama seminggu yang lalu. Jam kerja adalah waktu yang ditentukan untuk melakukan pekerjaan. Harrington (2001) menjelaskan bahwa jam kerja adalah waktu yang ditentukan untuk melakukan pekerjaan, lamanya jam kerja berlebih dapat meningkatkan human error atau kesalahan kerja karena kelelahan yang meningkat dan jam tidur yang berkurang. Selanjutnya dijelaskan bahwa tambahan durasi pada suatu shift kerja, akan meningkatkan tingkat kesalahan. Lima kali tambahan durasi shift per bulan akan meningkatkan kelelahan $300 \%$ dan berakibat fatal.

Dijelaskan bahwa jam kerja adalah waktu untuk melakukan pekerjaan, dapat dilaksanakan siang hari dan/atau malam hari. Jam kerja bagi para pekerja di sektor swasta diatur dalam Undang-Undang No.13 tahun 2003 tentang Ketenagakerjaan, khususnya pasal 77 sampai dengan pasal 85. Pasal 77 ayat 1, UndangUndang No.13/2003 mewajibkan setiap pengusaha untuk melaksanakan ketentuan jam kerja
(UU Ketenagakerjaan, 2003). Selanjutnya dijelaskan pemerintah mewajibkan setiap pengusaha untuk melindungi jam kerja para karyawannya. Jika karena suatu hal tertentu pengusaha mengharuskan karyawannya untuk bekerja diluar jam kerja yang ditetapkan, maka wajib membayar uang lembur kepada karyawannya.

\subsection{Hipotesis}

Berdasarkan

penelitian sebelumnya dan teori yang ada maka dapat diambil hipotesis secara parsial sebagai berikut:

1. Pendapatan suami, tingkat pendidikan, umur, dan kesempatan kerja berpengaruh signifikan terhadap jumlah jam kerja buruh wanita secara simultan.

2. Pendapatan suami berpengaruh signifikan terhadap jumlah jam kerja buruh wanita secara parsial.

3. Tingkat pendidikan berpengaruh signifikan terhadap jumlah jam kerja buruh wanita secara parsial. 
4. Umur berpengaruh signifikan terhadap jumlah jam kerja buruh wanita secara parsial.

\section{METODE PENELITIAN}

Penulis dalam hal ini mengambil lokasi penelitian di Gudang Tembakau "GMIT" Kabupaten Jember. Sedangkan waktu yang digunakan untuk mengadakan penelitian adalah selama 2 bulan yaitu : Bulan Mei-Juli 2017. Populasi dalam penelitian ini adalah seluruh buruh wanita yang sudah memiliki status menikah yang berjumlah 140 orang. Penentuan jumlah sampel yang digunakan pada penelitian ini menggunakan teknik Purposive Sampling yaitu teknik penentuan sampel dengan adanya pertimbangan-pertimbangan tertentu, antara lain: (a) seluruh buruh wanita dan (b) buruh wanita yang memiliki anak. Berdasarkan perhitungan sampel diketahui bahwa pada penelitian ini peneliti mengambil sampel sebanyak 58 orang. Sampel tersebut akan peneliti gunakan sebagai responden.
5. Kesempatan kerja berpengaruh signifikan terhadap jumlah jam kerja buruh wanita secara parsial.

Penelitian ini menggunakan jenis sekunder dan primer. Data primer adalah data yang diperoleh secara langsung dari responden dengan metode wawancara berdasarkan daftar pertanyaan yang telah disusun. Data yang dapat diperoleh secara langsung dari penelitian ini adalah pendapatan suami, umur, tingkatpendidikan, kesempatan kerja dan jam kerja. Sedangkan data sekunder adalahdata yang diperoleh dari literatur yang berkaitan dengan penelitian. Data padapenelitian ini diperoleh Gudang Tembakau "GMIT" Jember, laporan penelitian sebelumnya dan studi pustaka.

Analisis data dalam penelitian ini dilakukan dengan menggunakan bantuan program SPSS 18 untuk mempermudah dalam pengolahan dan analisis data. Tahapan yang dilakukan dalam data adalah: 
1. Uji asumsi klasik, meliputi uji normalitas, uji multikolinearitas, dan uji heteroskedastisitas.

2. Model regresi, analisis regresi linier berganda untuk mengetahui seberapa besar pengaruh variabel bebas terhadap variabel terikat.

3. Koefisien determinasi, bertujuan untuk mengukur seberapa jauh kemampuan model dalam menerangkan variasi dependen. Nilai koefisien determinasi adalah $0<\mathrm{R}^{2}<1$.

4. Uji hipotesis, meliputi uji $\mathrm{F}$ dan uji t. Uji $F$ digunakan untuk menguji hubungan pengaruh secara simultan atau secara bersama-sama semua variabel dependent berpengaruh terhadap variabel independen. $\mathrm{Uji} t$ digunakan untuk menguji signifikansi pengaruh secara parsial dari pendapatan suami, tingkat pendidikan, umur dan kesempatan kerja terhadap jumlah jam kerja. Uji $t$ ini digunakan untuk menguji hubungan pengaruh secara parsial atau secara mandiri masing-masing variabel dependen berpengaruh terhadap variabel independen.

\section{HASIL PENELITIAN DAN PEMBAHASAN}

\subsection{Hasil Penelitian}

Berikut ini adalah hasil uji asumsi klasik yang terdiri dari uji normalitas dan uji multikolinearitas. Dari grafik hasil uji normalitas terhadap model regresi yang dapat diketahui bahwa terlihat titik-titik menyebar di sekitar garis diagonal, serta penyebarannya mengikuti arah garis diagonal. Berdasarkan grafik uji normalitas dapat dikatakan bahwa model regresi layak dipakai karena telah memenuhi asumsi normalitas.

Berdasarkan hasil analisis Collinearity Statistic diketahui bahwa dalam model tidak terjadi multikolinearitas. Nilai VIF dari masing-masing variabel kurang dari 10. Semakin rendah nilai dari VIF, maka akan semakin baik karena tidak terjadi korelasi antar variabel independen.

Persamaan regresi linier berganda sebagai berikut: 


Y $=6,081+0,837 \mathrm{X}_{1}+0,016$
$\mathrm{X}_{2}+0,017 \mathrm{X}_{3}+0,024 \mathrm{X}_{4}$
Hasil koefisien determinasi
berganda $\left(\mathrm{R}^{2}\right)$ sebesar 0,802. Hal ini
berarti 80,2\% perubahan jumlah jam
kerja buruh wanita dipengaruhi oleh
variabel pendapatan suami, tingkat
pendidikan, umur, dan kesempatan
kerja sedangkan sisanya sebesar
19,8\% disebabkan oleh faktor lain
yang tidak termasuk dalam
persamaan regresi yang dibuat.

\section{Uji Simultan (Uji F)}

Hasil analisa menunjukkan bahwa Fhitung > Ftabel yaitu $31,029>5,36$ maka variabel pendapatan suami, tingkat pendidikan, umur, dan kesempatan kerja secara bersama-sama berpengaruh signifikan terhadap jumlah jam kerja pada tingkat signifikan 5\%, dalam hal ini $\mathrm{H}_{0}$ ditolak. Sehingga hipotesis yang menyatakan bahwa pendapatan suami, tingkat pendidikan, umur, dan kesempatan kerja secara bersama-sama berpengaruh signifikan terhadap jumlah jam kerja buruh wanita pada Gudang Tembakau “GMIT" Jember terbukti kebenarannya atau Ha1 diterima.
Semakin besar nilai Fhitung dari variabel pendapatan suami, tingkat pendidikan, umur, dan kesempatan kerja, maka pengaruh terhadap jumlah jam kerja yang ditimbulkan akan semakin kuat.

\section{Uji Parsial (Uji t)}

Hasil perhitungan uji t dengan menggunakan program SPSS for Windows dapat diketahui besarnya pengaruh masing-masing variabel bebas terhadap variabel terikat sebagai berikut:

a. Pengaruh Variabel Pendapatan Suami $\left(\mathrm{X}_{1}\right)$ terhadap Jumlah Jam Kerja (Y)

Diketahui bahwa hasil regresi persamaan kedua variabel menunjukkan $t_{\text {hitung }}$ $>t_{\text {tabel }}$ yaitu sebesar 2,466 > 1,658 dan tingkat probabilitas lebih kecil dari $\alpha$ yaitu $0,033<0,05$ maka $\mathrm{H}_{0}$ ditolak, berarti secara parsial variabel pendapatan suami $\left(\mathrm{X}_{1}\right)$ mempunyai pengaruh signifikan terhadap jumlah jam kerja (Y) dilingkungan Gudang Tembakau "GMIT" 
Jember. Semakin besar nilai $t_{\text {hitung dibandingkan dengan }}$ $\mathrm{t}_{\text {tabel }} \quad$ dari variabel pendapatan suami, maka pengaruh terhadap jumlah jam kerja secara parsial yang ditimbulkan akan semakin kuat. Dengan demikian $\mathrm{Ha}_{1}$ terbukti bahwa ada pengaruh pendapatan suami terhadap jumlah jam kerja buruh wanita pada Gudang Tembakau "GMIT" Jember.

b. Pengaruh Variabel Tingkat Pendidikan $\left(\mathrm{X}_{1}\right)$ terhadap Jumlah Jam Kerja (Y)

Diketahui bahwa hasil regresi persamaan kedua variabel menunjukkan $t_{\text {hitung }}$ $>t_{\text {tabe }} l$ yaitu sebesar 0,206 $>1,658$ dan tingkat probabilitas lebih kecil dari $\alpha$ yaitu $0,048<0,05$ maka $\mathrm{H}_{0}$ ditolak, berarti secara parsial variabel tingkat pendidikan mempunyai pengaruh signifikan terhadap jumlah jam kerja (Y) dilingkungan
Gudang Tembakau

"GMIT" Jember. Semakin besar nilai $t_{\text {hitung }}$ dibandingkan dengan $t_{\text {tabel }}$ dari variabel tingkat pendidikan, maka pengaruh terhadap jumlah jam kerja secara parsial yang ditimbulkan akan semakin kuat. Dengan demikian $\mathrm{Ha}_{2}$ terbukti bahwa ada pengaruh tingkat pendidikan terhadap jumlah jam kerja buruh wanita pada Gudang Tembakau “GMIT” Jember.

c. Pengaruh Variabel Umur $\left(\mathrm{X}_{1}\right)$ terhadap Jumlah Jam $\operatorname{Kerja~(Y)~}$

Diketahui bahwa hasil regresi persamaan kedua variabel menunjukkan $t_{\text {hitung }}$ $>t_{\text {tabel }}$ yaitu sebesar 2,420 > 1,658 dan tingkat probabilitas lebih kecil dari $\alpha$ yaitu $0,003<0,05$ maka $\mathrm{H}_{0}$ ditolak, berarti secara parsial variabel umur $\left(\mathrm{X}_{3}\right)$ mempunyai pengaruh signifikan terhadap jumlah jam kerja (Y) dilingkungan 
Gudang Tembakau

"GMIT" Jember. Semakin

besar nilai $t_{\text {hitung }}$

dibandingkan dengan $t_{\text {tabel }}$

dari variabel umur, maka

pengaruh terhadap jumlah

jam kerja secara parsial

yang ditimbulkan akan

semakin kuat. Dengan

demikian $\mathrm{Ha}_{3}$ terbukti

bahwa ada pengaruh umur

terhadap jumlah jam kerja

buruh wanita pada Gudang

Tembakau

"GMIT"

Jember.

d. Pengaruh Variabel

Kesempatan Kerja $\left(\mathrm{X}_{1}\right)$ terhadap Jumlah Jam Kerja (Y)

Diketahui bahwa hasil regresi persamaan kedua variabel menunjukkan $t_{\text {hitung }}$ $>t_{\text {tabel }}$ yaitu sebesar 2,064 > 1,658 dan tingkat probabilitas lebih kecil dari $\alpha$ yaitu $0,012<0,05$ maka $\mathrm{H}_{0}$ ditolak, berarti secara parsial variabel kesempatan kerja $\left(\mathrm{X}_{4}\right)$ mempunyai pengaruh signifikan terhadap jumlah jam kerja
(Y) dilingkungan Gudang

Tembakau "GMIT"

Jember. Semakin besar nilai $\mathrm{t}_{\text {hitung dibandingkan dengan }}$ $\mathrm{t}_{\text {tabel }} \quad$ dari variabel kesempatan kerja, maka pengaruh terhadap jumlah jam kerja secara parsial yang ditimbulkan akan semakin kuat. Dengan demikian $\mathrm{Ha}_{4}$ terbukti bahwa ada pengaruh kesempatan kerja terhadap jumlah jam kerja buruh wanita pada Gudang Tembakau "GMIT" Jember.

\subsection{Pembahasan}

Hasil uji regresi menunjukkan variabel pendapatan suami berpengaruh positif dan signifikan terhadap jumlah jam kerja dengan koefisien regresi sebesar 0,837 . Hal ini berarti variabel pendapatan suami yang diukur melalui indikator hasil jerih payah dan pemenuhan kebutuhan merupakan suatu faktor yang menentukan jumlah jam kerja buruh wanita pada Gudang Tembakau "GMIT" Jember. Hasil 
jerih payah suami digunakan sebagai ukuran untuk membiayai semua kebutuhan keluarga. Sedangkan pemenuhan kebutuhan hidup digunakan sebagai ukuran untuk mengukur tercukupinya kebutuhan hidup berdasarkan pendapatan suami.

Hasil uji regresi menunjukkan variabel tingkat pendidikan berpengaruh positif dan signifikan terhadap jumlah jam kerja dengan koefisien regresi sebesar 0,016. Hal ini berarti variabel tingkat pendidikan yang diukur melalui indikator jenjang pendidkan, pendidikan formal dan ketrampilan merupakan suatu faktor yang menentukan jumlah jam kerja buruh wanita pada Gudang Tembakau “GMIT" Jember. Tingkat pendidikan menggambarkan kualitas dan kemampuan seseorang dalam melakukan pekerjaan. Semakin tinggi tinggat pendidikan seseorang, maka semakin baik mutu jiwa dan kemampuan dalam menjalankan pekerjaannya (semakin baik pekerjaan yang dihasilkan). Demikian juga sebaliknya semakin rendah tingkat pendidikan, maka hasil pekerjaan tidak sesuai dengan ketentuan karena kemampuan yang rendah.

Hasil uji regresi menunjukkan variabel umur berpengaruh positif dan signifikan terhadap jumlah jam kerja dengan koefisien regresi sebesar 0,017. Hal ini berarti variabel umur yang diukur melalui indikator rentang waktu dan produktif merupakan suatu faktor yang menentukan jumlah jam kerja buruh wanita pada Gudang Tembakau "GMIT" Jember. Umur menggambarkan rentang waktu hidup seseorang digunakan untuk mengukur kematangan seseorang dalam mengambil keputusan dalam bertanggung jawab melakukan kegiatan yang produktif. Semakin tinggi umur seseorang, maka makin besar pula rasa tanggung jawab dalam menentukan keputusan dan makin produktif kegiatan yang dilakukan. Demikian juga sebaliknya semakin rendah umur seseorang, maka rendah pula rasa tanggung jawab yang dimiliki dan berakibat kurangnya produktif kegiatan yang dilakukan. 
Hasil uji regresi menunjukkan variabel kesempatan kerja berpengaruh positif dan signifikan terhadap jumlah jam kerja dengan koefisien regresi sebesar 0,024. Hal ini berarti variabel kesempatan kerja yang diukur melalui indikator lapangan kerja dan tenaga kerja merupakan suatu faktor yang

\section{KESIMPULAN DAN SARAN}

\subsection{Kesimpulan}

Berdasarkan hasil penelitian tentang pendapatan suami, tingkat pendidikan, umur dan kesempatan kerja terhadap jumlah jam kerja buruh wanita pada Gudang Tembakau "GMIT" Jember dapat diambil kesimpulan sebagai berikut:

1. Pendapatan suami mempunyai pengaruh secara signifikan dan positif terhadap jumlah jam kerja buruh wanita pada Gudang Tembakau "GMIT" Jember. Semakin rendahnya pendapatan suami dapat memberi kesempatan untuk meningkatkan jumlah jam kerja buruh wanita pada menentukan jumlah jam kerja buruh wanita pada Gudang Tembakau "GMIT" Jember. Semakin tinggi atau besar lapangan kerja yang tersedia, maka jumlah jam kerja akan semakin meningkat. Sebaliknya semakin rendah atau sedikut lapangan kerja yang tersedia, maka jumlah kerja semakin menurun.
Gudang Tembakau "GMIT" Jember.

2. Tingkat pendidikan mempunyai pengaruh secara signifikan dan positif terhadap jumlah jam kerja buruh wanita pada Gudang Tembakau "GMIT" Jember. Hal itu menyebabkan apabila tingkat pendidikan tinggi akan menghasilkan ketrampilan yang tinggi, sehingga meningkatkan jumlah jam kerja buruh wanita pada Gudang Tembakau "GMIT" Jember.

3. Umur mempunyai pengaruh signifikan dan positif terhadap jumlah jam kerja buruh wanita pada Gudang 
Tembakau "GMIT" Jember.

Dengan adanya umur yang cukup untuk bekerja dapat meningkatkan jumlah jam kerja buruh wanita pada Gudang Tembakau "GMIT" Jember.

4. Kesempatan kerja mempunyai pengaruh secara signifikan dan positif terhadap jumlah jam kerja buruh wanita pada Gudang Tembakau "GMIT" Jember. Hal ini menyebabkan apabila kesempatan kerja yang tinggi dapat meningkatkan jumlah jam kerja buruh wanita pada Gudang Tembakau "GMIT" Jember.

5. Faktor yang paling dominan berpengaruh terhadap jumlah jam kerja buruh wanita pada Gudang Tembakau "GMIT" Jember adalah pendapatan suami dengan koefisien regresi paling besar.

\subsection{Saran}

Berdasarkan kesimpulan yang diambil, maka dapat diambil beberapa saran sebagai berikut:
1. Dengan melihat hasil penelitian yang menunjukkan bahwa variabel yang paling dominan berpengaruh terhadap jumlah jam kerja buruh wanita pada Gudang Tembakau "GMIT" Jember adalah pendapatan suami maka agar produktivitas tetap tinggi maka pekerja wanita sebaiknya tetap bekerja dengan baik meskipun pendapatan suaminya tinggi, sehingga pendapatan keluarga juga akan lebih baik dan kesejahteraan dapat meningkat.

2. Adapun keterbatasan dari penelitian ini adalah masih kurangnya kelengkapan data dari dinas terkait. Dan seluruh variabel independen yaitu pendapatan suami, tingkat pendidikan, umur dan kesempatan kerja hanya dapat mempengaruhi variabel dependen jumlah jam kerja sebesar 0,802, hal ini berarti $80,2 \%$ 
dipengaruhi oleh variabel lain selain variabel dalam penelitian ini. Atas dasar keterbatasan tersebut, untuk

\begin{abstract}
penelitian selanjutnya diharapkan agar menambah variabel lain yang lebih variatif dari penelitian ini.
\end{abstract}

\section{DAFTAR PUSTAKA}

Arikunto, Suharsimi. 2013. Prosedur Penelitian: Suatu Pendekatan Praktik. PT. Rineka Cipta: Jakarta.

BPS. 2008. Produk Domestik Regional Bruto (PDRB). Jember: BPS: Jember. Bungin, B. 2005. Metodologi Penelitian Kuantitatif Komunikasi, Ekonomi dan Kebijakan Publikserta Ilmu - Ilmu Sosial Lainnya, Edisi Pertama, Cetakan Pertama. Prenada Media: Jakarta.

Erlina. 2011. Metode Penelitian. USU Press: Medan.

Kedokteran EGC: Jakarta.

Ghozali, Imam. 2011. Aplikasi Analisis Multivarian dengan Program SPSS. Universitas Diponegoro: Semarang.

Hasbullah. 2009. Dasar - Dasar Ilmu Pendidikan. PT. Raja Grafindo Persada: Jakarta.

Hurlock, E. B. 2007. Psikologi Perkembangan : Suatu Pendekatan Sepanjang Rentang Kehidupan. Erlangga: Surabaya.

Kamus Besar Bahasa Indonesia. Edisi Keempat. 2008. PT Gramedia Pustaka Utama: Jakarta.

Koentjoroningrat, 1997. Metode-Metode

Penelitian Masyarakat. Jakarta: Gramedia.
Mantra, Ida Bagoes. 2000. Demografi Umum. Pustaka Pelajar: Yogyakarta.

Margono. 2004. Metodologi Penelitian Pendidikan. Rineka Cipta: Jakarta.

Neolaka, Amos. 2014. Metode Penelitian dan Statistik. PT. Remaja Rosdakarya: Bandung.

Payaman J. Simanjuntak. 2001. Pengantar Ekonomi Sumber Daya Manusia Edisi 2001. FEUI: Jakarta.

Singarimbun, Masri \& Sofian Effendi. 2006. Metode Penelitian Survei. Pustaka LP3ES Indonesia: Jakarta.

Sugiyono. 2011. Statistika untuk Penelitian. Alfabeta: Bandung.

Sumardi, M \& Hans, D.E. 2005. Sumber Pendapatan Kebutuhan Pokok dan Perilaku Menyimpang. Rajawali: Jakarta.

Su'ud, H.. 2007. Manajemen Sumber Daya Manusia. Cetakan $V$. Pena: Banda Aceh.

Undang-Undang Republik Indonesia, Nomor 13 tahun 2003 tentang Ketenagakerjaan.

Undang-Undang Republik Indonesia Nomor 20 Tahun 2003 tentang Pendidikan Nasional. 